\title{
Primary carbonatite melt from deeply subducted oceanic crust
}

\author{
M. J. Walter ${ }^{1}$, G. P. Bulanova ${ }^{1}$, L. S. Armstrong ${ }^{1}$, S. Keshav ${ }^{2}$, J. D. Blundy ${ }^{1}$, G. Gudfinnsson ${ }^{2}$, O. T. Lord ${ }^{1}$, A. R. Lennie ${ }^{3}$, \\ S. M. Clark ${ }^{4}$, C. B. Smith ${ }^{5}$ \&. Gobbo ${ }^{6}$
}

Partial melting in the Earth's mantle plays an important part in generating the geochemical and isotopic diversity observed in volcanic rocks at the surface ${ }^{1}$. Identifying the composition of these primary melts in the mantle is crucial for establishing links between mantle geochemical 'reservoirs' and fundamental geodynamic processes ${ }^{2}$. Mineral inclusions in natural diamonds have provided a unique window into such deep mantle processes ${ }^{3-8}$. Here we provide experimental and geochemical evidence that silicate mineral inclusions in diamonds from Juina, Brazil, crystallized from primary and evolved carbonatite melts in the mantle transition zone and deep upper mantle. The incompatible trace element abundances calculated for a melt coexisting with a calcium-titanium-silicate perovskite inclusion indicate deep melting of carbonated oceanic crust, probably at transition-zone depths. Further to perovskite, calcic-majorite garnet inclusions record crystallization in the deep upper mantle from an evolved melt that closely resembles estimates of primitive carbonatite on the basis of volcanic rocks. Small-degree melts of subducted crust can be viewed as agents of chemical mass-transfer in the upper mantle and transition zone, leaving a chemical imprint of ocean crust that can possibly endure for billions of years.

The Juina region is well known as a source of 'ultra-deep' mineral inclusions in diamonds $s^{5,6,9,10}$. Here we report on mineral inclusions exposed by polishing three nitrogen-free type II diamonds (J1, J9 and J10) from the Collier 4 kimberlite pipe. Composite grains of calcium silicate $\left(\mathrm{CaSiO}_{3}\right)$ plus calcium titanate $\left(\mathrm{CaTiO}_{3}\right)$ are found in two diamonds, $\mathrm{J} 1$ and $\mathrm{J10}$, and three inclusions of calcic-majoritic garnet occur in diamonds $\mathrm{J1}$ and $\mathbf{3 9}$. Optical and cathodoluminescent observations are consistent with syngenesis of inclusions and host diamonds ${ }^{11}$.

As shown in Fig. 1a, two chemically distinct regions in the composite grains have nearly end-member compositions in the system $\mathrm{CaTiO}_{3}-\mathrm{CaSiO}_{3}$ (Supplementary Table 1), indicative of unmixing from originally homogeneous minerals. Although rare, other composite inclusions of $\mathrm{CaTiO}_{3}$ and $\mathrm{CaSiO}_{3}$ have recently been reported in Juina detrital diamonds $s^{6,9,10,12}$. Previous workers have interpreted these grains as retrograde exsolution products from pre-existing, single-phase $\mathrm{Ca}(\mathrm{Ti}, \mathrm{Si}) \mathrm{O}_{3}$-perovskite solid solutions originating at transition zone or lower mantle depths, and their compositions were used as evidence of deep subduction of a Ca-rich lithology, ${ }^{9,12}$.

High-pressure phase relations in the system $\mathrm{CaTiO}_{3}-\mathrm{CaSiO}_{3}$ show immiscibility at pressures of less than about $9 \mathrm{GPa}$ at $1,200^{\circ} \mathrm{C}$ (Fig. 1a) ${ }^{13}$. We interpret the composite inclusions in $\mathrm{J} 9$ and $\mathrm{J} 10$ as retrograde perovskite solid solutions that unmixed on diamond exhumation from deeper in the mantle to final equilibration pressures of 6 to $7 \mathrm{GPa}(\sim 250 \mathrm{~km})$, as deduced from the $\mathrm{CaSiO}_{3}$ content of the $\mathrm{CaTiO}_{3}$-rich phase. Figure 1 shows that a complete perovskite solid solution exists for the estimated inclusion compositions at pressures of greater than $\sim 9$ to $11 \mathrm{GPa}\left(1,200^{\circ} \mathrm{C}\right)$, indicating that their primary depth of origin is a minimum of about $300 \mathrm{~km}$.

The garnets in diamonds $\mathrm{J} 1$ and $\mathrm{J} 9$ have minor majorite components but are conspicuous in their very high $\mathrm{CaO}$ contents $(\sim 8-15 \mathrm{wt} \%)$, near absence of $\mathrm{Cr}_{2} \mathrm{O}_{3}(<0.05 \%)$, and high $\mathrm{Na}_{2} \mathrm{O}$ and $\mathrm{TiO}_{2}$ (Supplementary Table 1), all features typically interpreted as 'eclogitic', genetically linking the minerals to subducted oceanic crust". On the basis of the composition of the garnet near the rim of $\mathrm{J} 1$, an equilibration pressure of about $7 \mathrm{GPa}$ is indicated (Fig. 1b), consistent with the pressure deduced for the centrally located perovskite inclusion.

Further constraints on the petrogenesis and primary depth of origin of the perovskite inclusions come from high-pressure phase relations as depicted in the system $\mathrm{CaSiO}_{3}-\mathrm{CaTiO}_{3}-\mathrm{MgSiO}_{3}$. The perovskite inclusions show a near absence of $\mathrm{MgSiO}_{3}$ component ( $\leq 0.2 \mathrm{~mol} \%$ ), a feature noted previously for Ti-poor $\mathrm{CaSiO}_{3}$-perovskite inclusions in diamond ${ }^{5,14}$. At transition zone and lower mantle depths, Ca-rich perovskite in mantle peridotite and eclogite is saturated in $\mathrm{MgSiO}_{3}$ component because it coexists with either majorite-rich garnet or $\mathrm{Mg}$-rich perovskite. Inclusions that represent entrapped mantle minerals should also show $\mathrm{MgSiO}_{3}$ saturation. Figure $2 \mathrm{a}$ shows high-pressure experimental data from the literature for the compositions of Ca-perovskite coexisting with majorite or $\mathrm{Mg}$-perovskite in natural peridotite and eclogite bulk compositions ${ }^{15-17}$ as projected onto the $\mathrm{CaSiO}_{3}-\mathrm{CaTiO}_{3}-\mathrm{MgSiO}_{3}$ plane. At the experimental temperatures $\left(1,200-2,430^{\circ} \mathrm{C}\right)$, Ca-perovskite has about 3 to $5 \mathrm{~mol} \% \mathrm{MgSiO}_{3}$ component, which is much more than observed in diamond-hosted inclusions. Furthermore, the $\mathrm{CaTiO}_{3}$-component of $\mathrm{Ca}$-rich perovskites, even in more Tirich eclogitic compositions, is much lower than in the inclusions in $\mathrm{J} 1$ and $\mathrm{J} 10$.

To determine the effects of titanium on $\mathrm{MgSiO}_{3}$ solubility in $\mathrm{Ca}(\mathrm{Ti}, \mathrm{Si}) \mathrm{O}_{3}$-perovskite solid solutions saturated in Mg-perovskite, we made high pressure experiments in the system $\mathrm{CaSiO}_{3}-\mathrm{CaTiO}_{3}$ $\mathrm{MgSiO}_{3}$ and the results are shown in Fig. 2b. We found that at all pressures investigated (from 20 to $50 \mathrm{GPa}, 1,227-2,227^{\circ} \mathrm{C}$ ) the $\mathrm{MgSiO}_{3}$ solubility in $\mathrm{Ca}$-perovskite increased substantially with $\mathrm{Ti}$ content. Phase relations show that $\mathrm{Ti}$-rich $\mathrm{Ca}(\mathrm{Ti}, \mathrm{Si}) \mathrm{O}_{3}$-perovskites have an abundant $\mathrm{MgSiO}_{3}$ component when coexisting with $\mathrm{Mg}$ perovskite. The near absence of $\mathrm{MgSiO}_{3}$ component in perovskite inclusions in $\mathrm{J} 1$ and $\mathrm{J} 10$ effectively precludes an origin in Ti-rich, $\mathrm{MgSiO}_{3}$-saturated lithologies at lower mantle conditions. Thus, our observations to this point constrain the depth of origin of the perovskite inclusions to between about $300 \mathrm{~km}$ and the onset of $\mathrm{Mg}$ perovskite stability $(\sim 670-700 \mathrm{~km})$, and also apparently make a subsolidus origin in either peridotite or eclogite highly improbable.

'Department of Earth Sciences, University of Bristol, Queen's Road, Bristol BS8 1RJ, UK. ${ }^{2}$ Bayerisches Geoinstitut, Universität Bayreuth, D-95440 Bayreuth, Germany. ${ }^{3}$ Daresbury Laboratory, Keckwick Lane, Warrington WA4 4AD, UK. ${ }^{4}$ Advanced Light Source, Lawrence Berkeley National Laboratory, 1 Cyclotron Road, Berkeley, California 94720, USA. ${ }^{5}$ Rio Tinto Mining and Exploration Ltd., Paddington, London W2 6LG, UK. ${ }^{6}$ Rio Tinto Desinvolvimentos Minerais Ltda, SIA Trecho 2, Lote 720, Brasilia, DF 71.200-020, Brazil. 
Further evidence for the petrogenesis of the mineral inclusions comes from their trace element chemistry. We analysed perovskite and garnet inclusions in diamonds $\mathrm{J} 1$ and $\mathrm{J} 9$ for trace elements using a secondary ion microprobe at the University of Edinburgh. Data are presented on relative compatibility 'spidergrams' in Fig. 3a, and show extremely elevated abundances of many 'magmaphile' trace elements when normalized to primitive mantle ${ }^{18}$. The extreme enrichment in elements such as thorium, niobium and the rare earth elements (REE) is hard to reconcile with subsolidus paragenesis in lithologies such as peridotite, harzburgite or eclogite. For example, caesium is present in the $\mathrm{J} 1 \mathrm{CaTiSi}$-perovskite at a level of $\sim 10^{4}$ relative to primitive mantle. Even if this inclusion represents only $0.1 \%$ of a mantle lithology, it would still yield a bulk composition enriched by at least 10 times primitive mantle. In contrast, extreme enrichment in incompatible elements is consistent with, and often signatory of, the involvement of a low-degree melt. Considering the inclusions are hosted in diamond, the melt must also be sufficiently carbon-rich to
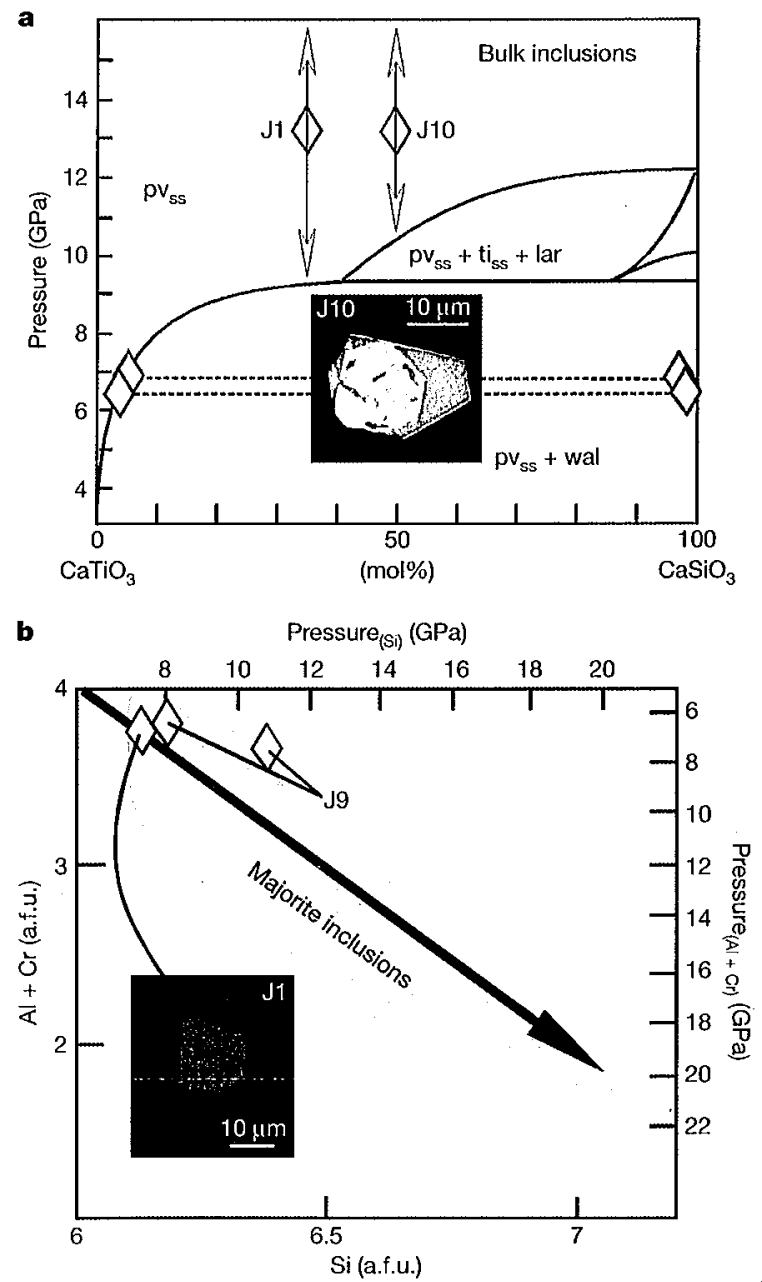

Figure 1 | Mineral chemistry and geobarometry of perovskite and garnet mineral inclusions in Juina diamonds. a, Phase relations in the system $\mathrm{CaTiO}_{3}-\mathrm{CaSiO}_{3}$ at $1,200^{\circ} \mathrm{C}$ (ref. 13). Shown on the diagram are the compositions of the $\mathrm{CaSiO}_{3}$ and $\mathrm{CaTiO}_{3}$ regions of the composite inclusions in diamonds J1 and J10. Estimates of the bulk inclusion compositions on the basis of area proportion are also shown. Inset, back-scattered electron image of inclusion J10. On the basis of the $\mathrm{CaSiO}_{3}$ component of the $\mathrm{CaTiO}_{3}$ phase, exsolution pressures of 6 to $7 \mathrm{GPa}$ are indicated. lar, larnite; pv, perovskite; ss, solid solution; ti, titanite; wal, walstromite. b, Systematics of $(\mathrm{Al}+\mathrm{Cr})$ versus Si per atomic formula unit (a.f.u.) in garnet inclusions from diamonds $\mathrm{J} 1$ and $\mathrm{J} 9$. Calibration of this relationship as a barometer, giving pressure shown as Pressure ${ }_{(\mathrm{Si})}$, indicates equilibration pressures of 7 (JI) to 11 (J9) GPa for these inclusions ${ }^{7}$. Scale bars, $10 \mu \mathrm{m}$. saturate in diamond. Previous experiments confirmed that reduction of carbonate-rich melt is an effective means of diamond synthesis in mantle silicates ${ }^{19,20}$.

To test further our hypothesis that the mineral inclusions crystallized from carbon-rich low-degree melts, we performed melting experiments in the system $\mathrm{CaO}-\mathrm{MgO}-\mathrm{Al}_{2} \mathrm{O}_{3}-\mathrm{SiO}_{2}-\mathrm{TiO}_{2}-\mathrm{CO}_{2}$. Because of the eclogitic characteristics of the inclusions, we chose a

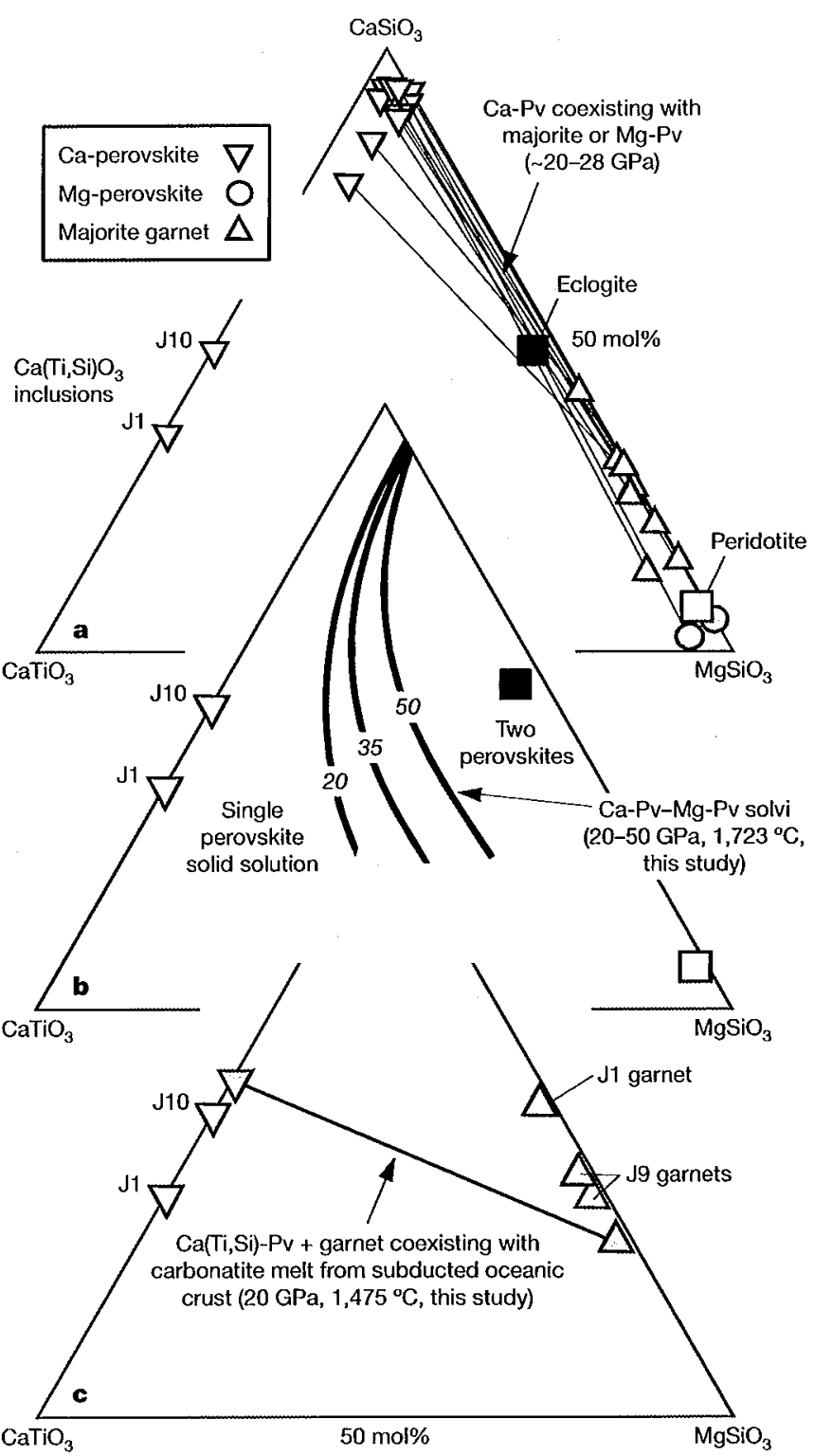

Figure 2 | Subsolidus and melting phase relations in the compositional join $\mathrm{CaTiO}_{3}-\mathrm{CaSiO}_{3}-\mathrm{MgSiO}_{3}$. The estimated compositions of the composite inclusions in diamonds $\mathrm{J} 1$ and $\mathrm{J} 10$ are shown as inverted white triangles. Projected bulk compositions of natural eclogite and peridotite are shown as black and white squares, respectively. a, Ca-perovskite (Ca-Pv) coexisting with majorite or $\mathrm{Mg}$-perovskite ( $\mathrm{Mg}-\mathrm{Pv}$ ) as determined in previous experiments on natural peridotite and eclogite bulk compositions at 20 to 28 GPa and $1,200-2,430^{\circ} \mathrm{C}$ (refs 15-17). Ca-rich perovskites are shown as inverted dark triangles, majorite as dark triangles, and $\mathrm{Mg}$-perovskites as dark circles. $b$, The boundary curves show the solubility of the $\mathrm{MgSiO}_{3}$ component in $\mathrm{Ca}(\mathrm{Si}, \mathrm{Ti}) \mathrm{O}_{3}$-perovskite solid solution coexisting with $\mathrm{Mg}$ perovskite $(\mathrm{CaPv}-\mathrm{MgPv})$ at $20-50 \mathrm{GPa}$ and $1,723^{\circ} \mathrm{C}$ as determined in this study. c, The compositions of $\mathrm{Ca}(\mathrm{Si}, \mathrm{Ti}) \mathrm{O}_{3}$-perovskite solid solution (inverted dark triangle) that coexist with calcic majorite (dark triangle) and Ca-rich carbonatite melt from model carbonated eclogite at $20 \mathrm{GPa}, 1,475^{\circ} \mathrm{C}$ as determined in this study. Garnet inclusions from diamonds J1 and J9 are shown as white triangles. 
model oceanic crust composition. Figure $2 \mathrm{c}$ shows the compositions of $\mathrm{Ca}(\mathrm{Ti}, \mathrm{Si}) \mathrm{O}_{3}$-perovskite and majorite coexisting with carbonated melt at $20 \mathrm{GPa}$ and $1,475^{\circ} \mathrm{C}$. We find that carbonatite melt from model eclogite is $\mathrm{TiO}_{2}$ and $\mathrm{CaO}$ rich $\left[(\mathrm{Ca} /(\mathrm{Ca}+\mathrm{Mg}))_{\text {molar }} \approx 0.7\right]$. The coexisting $\mathrm{Ca}(\mathrm{Ti}, \mathrm{Si}) \mathrm{O}_{3}$-perovskite has a high $\mathrm{Ti}$ content and a very low $\mathrm{MgSiO}_{3}$ content that is consistent with the compositions of the perovskite inclusions in $\mathrm{J} 1$ and $\mathrm{J} 10$. The coexisting majorite garnet is very calcic ${ }^{21}$, with a composition akin to the calcic garnet inclusions. Thus, the major-element mineral chemistry and the elevated trace element abundances are consistent with crystallization of the inclusions from carbonatitic melts derived from eclogite in the mantle transition zone.

We quantitatively calculated the trace element $(i)$ concentrations of melts that could coexist with the mineral inclusions using the relation $C_{i}^{\text {melt }}=C_{i}^{\text {solid }} / D$, where the solid concentrations, $C_{i}^{\text {solid }}$, and mineral melt partition coefficients, $D$, are known ${ }^{21,22}$ (Supplementary Tables 1 and 2). The melt calculated to coexist with CaTiSi-perovskite, or 'perovskite melt', is shown in Fig. $3 \mathrm{~b}$ and has enriched but relatively unfractionated REE (lanthanum/lutetium $\sim 5$ ), is not depleted in the high field strength elements (HFSE) titanium, hafmium, zirconium and niobium, but is strongly depleted in the large ion lithophile elements (LILE) strontium, barium and rubidium relative to other elements of similar incompatibility.

The characteristics of the perovskite melt are qualitatively explicable in terms of the relative abundances of elements expected in deeply subducted oceanic crust. During subduction and slab dehydration in the upper mantle the LILE can be highly soluble in the fluids and melts expelled from oceanic crust, whereas REE and HFSE may be retained in minerals such as garnet (heavy REE), allanite (light $\mathrm{REE}$ ) and rutile (HFSE) ${ }^{23-25}$. On the basis of the characteristic trace element concentrations-together with the major-element constraints provided above-we propose that the CaTiSi-perovskite inclusion in J1 crystallized from a low-degree, primary carbonatite melt derived from deeply subducted oceanic crust.

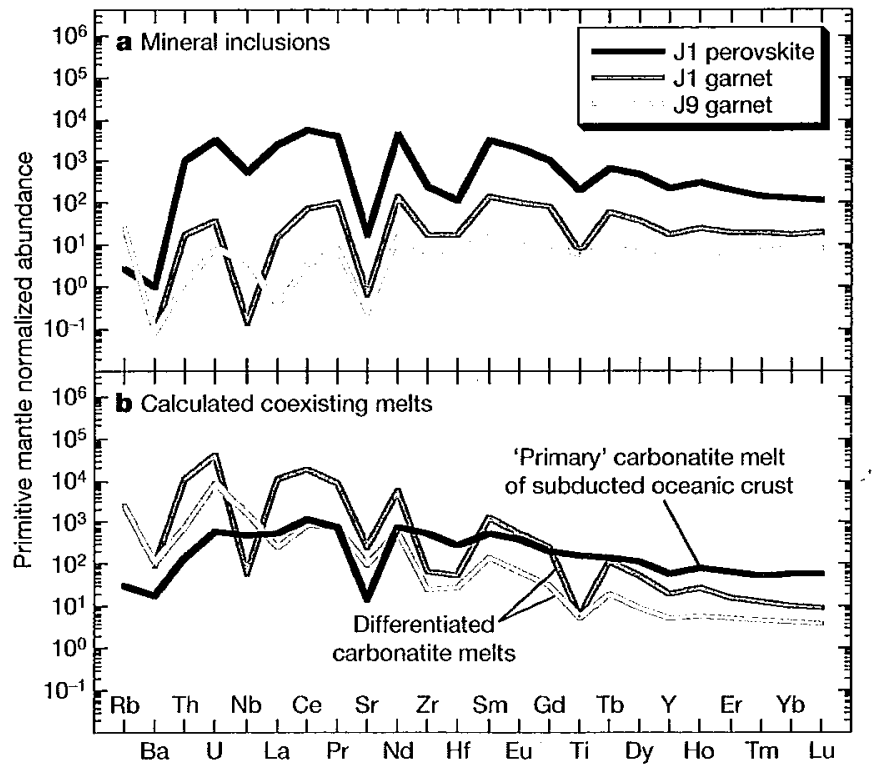

Figure 3 | Relative compatibility diagrams showing trace element abundances of mineral inclusions and calculated coexisting melts. Data are normalized to primitive mantle ${ }^{18}$. a, Element abundances measured by SIMS in $\mathrm{Ca}(\mathrm{Ti}, \mathrm{Si}) \mathrm{O}_{3}$ inclusions in diamond $\mathrm{J} 1$ and $\mathrm{Ca}$-rich majorite garnets in $\mathrm{J} 1$ and J9. b, Calculated melts that could coexist with the mineral inclusions. Melt compositions were calculated using experimental mineral/melt partition coefficients from the literature appropriate to the pressure-temperature conditions of the lowermost upper mantle and transition zone (see Supplementary Table 2).
The melts calculated to coexist with majoritic garnets ('majorite melt') are also highly enriched but show several distinguishing features (Fig. 3b). The REE are much more fractionated (lanthanum/ lutetium $\sim 10^{2}$ to $10^{3}$ ) and there are large relative depletions in HFSE, especially for the $\mathrm{J} 9$ garnet. We suggest that the majorite melt is either evolved from a primary melt by fractionation of high-pressure phases such as majorite and ilmenite, or perhaps it is derived from a secondary melt of mantle peridotite previously metasomatized by carbonatitic melts from eclogite. For example, a primary calciccarbonatite melt may form in the transition zone and crystallize liquidus minerals including diamond and Ca'TiSi-perovskite in an eclogite body. Migration of such melt into peridotite should cause dissolution of magnesium silicate minerals and solidification. Later upwelling of this metasomatized mantle, perhaps related to plume upwelling or flow of material around a deepening cratonic keel, may cause metasomatized mantle to melt forming a new more Mg-rich carbonatite from which diamond and majorite crystallize.

Figure 4 shows the trace-element abundances of melts calculated to coexist with calcic-majorite garnet inclusions from this study and the literature. These are compared with literature estimates of primitive carbonatite magmas on the basis of volcanic rocks, and to carbonatitic glasses in xenoliths from ocean island basalts ${ }^{26-31}$. The fields show similarities both in absolute concentrations and in patterns, suggesting that the calculated majorite melts exemplify a pervasive metasomatizing component in the deep upper mantle, which is identifiable in xenolith glasses, xenolith mineral chemistry, ocean island basalt magma chemistry and diamond inclusions ${ }^{21,26-29,32}$. We suggest that this widely dispersed and chemically distinct signature is imparted by low-degree carbonatite melt derived ultimately from subducted oceanic crust.

Our study of diamond-hosted minerals from Juina suggests a process whereby subducted, carbonated oceanic crust undergoes lowdegree partial melting to produce trace-element-rich carbonatite melts. The mantle transition zone is a plausible location for crustal melting as slabs may founder owing to the density crossover between eclogite and peridotite ${ }^{17,33}$, and could heat up to temperatures of the carbonated eclogite solidus. The distinctive chemical 'flavour' of primary carbonatites, particularly their oceanic crustal signatures and extreme enrichment in trace elements, ensures that the consequences of their passage are preserved for very long timescales, even in rocks that have long since lost any carbonate component through low-pressure decarbonation reactions. As metasomatic agents, carbonatites in effect impart a 'stain' on mantle rocks that can persist for billions of years, and which can in turn impart a unique chemical and isotopic signature to mantle-derived magmas erupted at the Earth's surface.

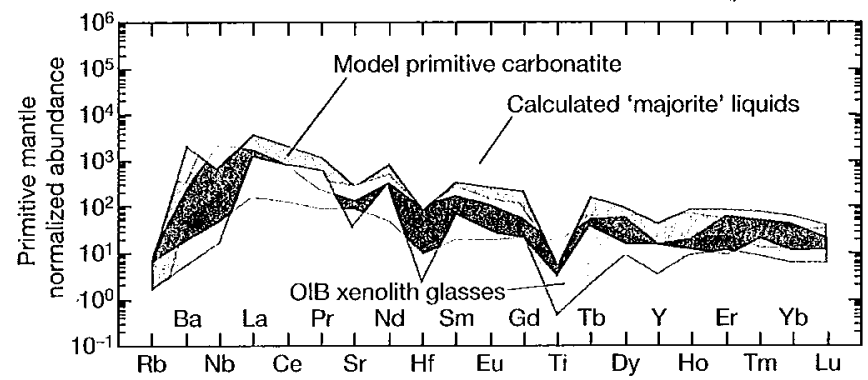

Figure 4 | Relative compatibility diagrams showing trace element abundances of model primitive carbonatites normalized to primitive mantle. The light shaded field shows calculated melts that could coexist with calcic majorite garnets from this study and one previously described ${ }^{31}$. The dark shaded field shows estimates of primitive carbonatite compositions from the literature $\mathrm{e}^{27,30}$, and the intermediate shaded field shows the composition of glasses trapped in mantle xenoliths from ocean island basalts $(\mathrm{OIB})^{26,28,29}$. 


\section{METHODS SUMMARY}

We exposed mineral inclusions in situ by polishing diamonds along dodecahedral planes. Cathodoluminescence imaging of polished diamond slabs confirmed that the inclusions are not in proximity to cracks, suggestive of syngenesis with the diamond hosts. Major and minor element compositions of the inclusions were determined with a Cameca SX100 electron microprobe at the University of Bristol, operated at $20 \mathrm{nA}$ and $15 \mathrm{kV}$ and calibrated against silicate and oxide standards. Trace element concentrations were measured with a Cameca IMS-4f ion-microprobe at the University of Edinburgh using an $11 \mathrm{keV}$ primary beam of ${ }^{16} \mathrm{O}^{-}$ions, a sample current of $2 \mathrm{nA}$ and secondary ion accelerating voltage of $4,500 \mathrm{~V}$, with glass standards as calibrants.

Subsolidus experiments in the system $\mathrm{CaSiO}_{3}-\mathrm{CaTiO}_{3}-\mathrm{MgSiO}_{3}$ were performed at Bristol in a laser-heated diamond anvil cell. Ground glass starting materials with Pt-black were contained in stainless-steel gaskets with pressure measured by ruby fluorescence. Samples were compressed to 20-50 GPa and heated simultaneously on both sides for $30-60 \mathrm{~min}$ at $1,227-2,227^{\circ} \mathrm{C}$; temperature was measured using standard spectroradiometric techniques. Angle dispersive powder diffraction patterns of $\mathbf{P}-\mathrm{T}$ quenched samples were collected using focused synchrotron $\mathrm{X}$-ray diffraction techniques at the Synchrotron Radiation Source in Daresbury, UK, and the Advanced Light Source in Berkeley, USA. Phases were indexed on the basis of space groups Pbnm for $\mathrm{Mg}$-perovskite and $\mathrm{Pm} 3 \mathrm{~m}$ for $\mathrm{Ca}(\mathrm{Ti}, \mathrm{Si}) \mathrm{O}_{3}$ perovskite.

A melting experiment in the system $\mathrm{CaO}-\mathrm{MgO}-\mathrm{Al}_{2} \mathrm{O}_{3}-\mathrm{SiO}_{2}-\mathrm{TiO}_{2}-\mathrm{CO}_{2}$ was made using multi-anvil techniques at Bayerisches Geoinstitut, Germany. Powdered glass and magnesite starting mixture was placed within a platinum capsule and run at $20 \mathrm{GPa}$ and $1,475^{\circ} \mathrm{C}$ in an octahedral pressure cell, with 10 $\mathrm{mm}$ edge lengths and tungsten carbide cubes with $5-\mathrm{mm}$ corner truncations, using a 1,200 ton press. Electron microprobe analyses of run products were made with a JEOL JXA-8900 microprobe at Bayerisches Geoinstitut using silicate and oxide standards, a beam current of $15 \mathrm{nA}$ and a $15 \mathrm{kV}$ voltage.

Full Methods and any associated references are available in the online version of the paper at www.nature.com/nature.

Received 13 January; accepted 28 May 2008.

1. Hofmann, A. W. Mantle geochemistry: the message from oceanic volcanism. Nature 385, 219-229 (1997)

2. Zindler, A. \& Hart, S. R. Chemical geodynamics. Annu. Rev. Earth Planet. Sci. 14, 493-571 (1986).

3. Haggerty, S. E. in Mantle Petrology: Field Observations and High Pressure Experimentation (eds Fei, Y., Bertka, C. M. \& Mysen, B. O.) 105-123 (Geochemical Society Special Publications, 1999).

4. Harte, B. \& Harris, J. W. Lower mantle mineral association preserved in diamonds. Miner. Mag. A 58, 384-385 (1994).

5. Harte, B., Harris, J. W., Hutchison, M. T., Watt, G. R. \& Wilding, M. C. in Mantle Petrology: Field observations and High Pressure Experimentation (eds Fei, Y., Bertka, C. M. \& Mysen, B. O.) 125-153 (Geochemical Society Special Publications, Houston, 1999).

6. Kaminsky, F. et al. Superdeep diamonds from the Juina area, Mato Grosso State, Brazil. Contrib. Mineral. Petrol. 140, 734-753 (2001).

7. Stachel, T. Diamonds from the asthenosphere and the transition zone. Eur. J. Mineral. 13, 883-892 (2001)

8. Tappert, R. et al. Subducting oceanic crust: The source of deep diamonds. Geology 33, 565-568 (2005).

9. Brenker, F. E. et al. Detection of a Ca-rich lithology in the Earth's deep (>300 km) convecting mantle. Earth Planet. Sci. Lett. 236, 579-587 (2005).

10. Hayman, P. C., Kopylova, M. G. \& Kaminsky, F. V. Lower mantle diamonds from Rio Soriso (Juina area, Mato Grosso, Brazil). Contrib. Mineral. Petrol. 149, 430-445 (2005)

11. Bulanova, G. P. The formation of diamond. J. Geochem. Exp. 53, 1-23 (1995).

12. Brenker, F. E. et al. Carbonates from the lower part of transition zone or even the lower mantle. Earth Planet. Sci. Lett. 260, 1-9 (2007).

13. Kubo, A., Suzuki, T. \& Akaogi, M. High pressure phase equilibria in the system $\mathrm{CaTiO}_{3}-\mathrm{CaSiO}_{3}$ : stability of perovskite solid solutions. Phys. Chem. Mineral. 24, 488-494 (1997).

14. Stachel, T., Harris, J. W., Brey, G. \& Joswig, W. Kankan diamonds (Guinea) II: lower mantle inclusion paragenesis. Contrib. Mineral. Petrol. 140, 16-27 (2000).

15. Hirose, K. \& Fei, Y. Subsolidus and melting phase relations of basaltic composition in the uppermost lower mantle. Geochim. Cosmochim. Acta 66, 2099-2108 (2002)
16. Hirose, K., Shimizu, N., vanWestrenan, W. \& Fei, Y. Trace element partitioning in Earth's lower mantle and implications for geochemical consequences of partial melting at the core-mantle boundary. Phys. Earth Planet. Inter. 146, 249-260 (2004).

17. Irifune, T. \& Ringwood, A. E. Phase transformations in subducted oceanic crust and buoyancy relationships at depths of $600-800 \mathrm{~km}$ in the mantle. Earth Planet Sci. Lett. 117, 101-110 (1993)

18. McDonough, W. F. \& Sun, S.-s. The composition of the Earth. Chem. Geol. 120 223-253 (1995).

19. Safonov, O. G., Perchuk, L. L. \& Litvin, Y. A. Melting relations in the chloride-carbonate-silicate systems at high-pressure and the model for formation of alkalic diamond - forming liquids in the upper mantle. Earth Planet. Sci. lett. 253, 112-128 (2007)

20. Arima, M., Kozai, Y. \& Akaishi, M. Diamond nucleation and growth by reduction of carbonate melts under high-pressure and high-temperature conditions. Geology 30, 691-694 (2002)

21. Keshav, S., Gudfinnsson, G.\& Presnall, D. Majoritic-garnets and clinopyroxenes in cratonic diamonds: Precipitates from $\mathrm{CO}_{2}$-rich melts. Proc. 11th Int. Conf. EMPG abstr. 36 (2006)

22. Corgne, A. \& Wood, B. J. $\mathrm{CaSiO}_{3}$ and $\mathrm{CaTiO}_{3}$ perovskite-melt partitioning of trace elements: implications for gross mantle differentiation. Geophys. Res. Lett. 29, doi:10.1029/2001GL014398 (2002).

23. Brenan, J. M., Shaw, H. F., Ryerson, F. J. \& Phinney, D. L. Mineral-aqueous fluid partitioning of trace elements at $900^{\circ} \mathrm{C}$ and $2.0 \mathrm{GPa}$ : Constraints on the trace element chemistry of mantle and deep crustal fiuids. Geochim. Cosmochim. Acta 59, 3331-3350 (1995).

24. Kessel, R., Schmidt, M., Ulmer, P. \& Pettke, T. Trace element signature of subduction-zone fluids, melts and supercritical liquids at $120-180 \mathrm{~km}$ depth. Nature 437, 724-727 (2005).

25. Manning, C. E. The chemistry of subduction-zone fluids. Earth Planet. Sci. Lett. 223, 1-16 (2004).

26. Coltorti, M., Bonadiman, C., Hinton, R. W., Siena, F. \& Upton, B. G. J. Carbonatite metasomatism of the oceanic upper mantle: Evidence from clinopyroxenes and glasses in ultramafic xenoliths of Grande Comore, Indian Ocean. J. Petrol. 40, 133-165 (1999).

27. Harmer, R. E. \& Gittins, J. The case for primary, mantle-derived carbonatite magma. J. Petrol. 39, 1895-1903 (1998)

28. Hauri, E., Shimizu, N., Dieu, J. J. \& Hart, S. R. Evidence for hotspot-related carbonatite metasomatism in the oceanic upper mantle. Nature $365,221-227$ (1993).

29. Ionov, D. A. Trace element composition of mantle-derived carbonates and coexisting phases in peridotite xenoliths from alkali basalts. J. Petrol. 39. 1931-1941 (1998).

30. Kogarko, L. N. Geochemical characteristics of oceanic carbonatites from Cape Verde Islands. S. Afr. J. Geol. 96, 119-125 (1993).

31. Stachel, T., Brey, G. \& Harris, J. W. Kankan diamonds (Guinea) I: from the lithosphere down to the transition zone. Contrib. Mineral. Petrol. 140, 1-15 (2000)

32. Dasgupta, R., Hirschmann, M. M. \& Withers, A. C. Deep global cycling of carbon constrained by the solidus of anhydrous, carbonated eclogite under upper mantle conditions. Earth Planet. Sci. Lett. 227, 73-85 (2004).

33. Hirose, K., Fei, Y., Ma, Y. \& Mao, H.-K. The fate of subducted basaltic crust in the Earth's lower mantle. Nature 397, 53-56 (1999).

Supplementary Information is linked to the online version of the paper at www.nature.com/nature

Acknowledgements Diamond samples from Collier 4 were collected by Rio Tinto (Rio Tinto Desenvolvimentos Minerais Ltda) in 1994. We thank Rio Tinto for access to the collection and J. Pickles for technical assistance. This work was supported by an NERC grant to M.J.W. Experiments by L.S.A. at Bayerisches Geoinstitut were supported by the Marie Curie 6th Framework Programme. Synchrotron experiments at Synchrotron Radiation Source, Daresbury Laboratory, UK, and at the Advanced light Source, Berkeley, USA, were supported by awards to M.J.W. Trace element analyses at the NERC Edinburgh Ion Microprobe Facility were supported by an award to M.J.W.

Author Contributions M.J.W., G.P.B, J.D.B. and C.B.S. formulated the project M.J.W., L.S.A., S.K., G.G., O.T.L., A.R.L. and S.M.C. were responsible for experimental and analytical data collection. G.P.B. was responsible for diamond sample preparation. L.G. processed the kimberlite to recover diamonds and selected inclusion-bearing stones for the project. M.J.W. wrote the manuscript with assistance from G.P.B., L.S.A., S.K., J.D.B., A.R.L. and C.B.S

Author Information Reprints and permissions information is available at www.nature.com/reprints. Correspondence and requests for materials should be addressed to M.J.W. (m.j.walter@bris.ac.uk).

This work was supported by the U.S. Department of Energy under Contract No. DE-AC02-05CH11231. 


\section{METHODS}

The diamonds are $2-4 \mathrm{~mm}$ colourless octahedron/dodecahedron transition forms. Diamonds J9 and J10 are whole crystals; stone J1 is mostly whole but with minor breakage along the dodecahedral plane. The diamond faces are resorbed, heavily etched and the broken surface of the JI crystal is also covered by natural etch patterns. Observation of the whole stones in photoluminescence light shows their dark-blue colour and lack of prominent zonation. Pyrhotite inclusions are present in $\mathrm{Jl}$ and $\mathrm{J} 10$ stones in addition to silicates and are surrounded by a rosette of local black cracks. Optical microscopy of the unpolished diamond did not show any cracks associated with the silicate inclusions. Cathodoluminescence imaging of polished diamond plates with the CaTiSiphase exposed shows that the inclusions have no cracks going to the surface and are located deep within the diamonds, consistent with syngenetic growth with the diamond hosts. Further, inclusion morphologies show imposed negative diamond shapes, also supporting a syngenetic interpretation. The same applies to the majorite in 19 stone. On the basis of the cathodoluminescence imaging, the $\mathrm{Jl}$ garnet inclusion is located either in a small diamond intergrowth or in a small diamond block surrounded by an ancient re-healed crack.

Electron microprobe analysis of diamond inclusions was made at University of Bristol with a Cameca SX100 using silicate and oxide standards. We used a beam current of $20 \mathrm{nA}$ and a $15 \mathrm{kV}$ voltage. Conventional $\mathrm{ZAF}$ data reduction techniques were used. Replicate analysis of standards yielded uncertainties at the $2 \%$ and $5 \%$ level for major and minor elements, respectively. Trace elements were determined using a Cameca IMS-4f ion-microprobe at the NERC Edinburgh Ion Microprobe Facility, University of Edinburgh. The primary beam was $\sim 11 \mathrm{keV}^{16} \mathrm{O}^{-}$ions ( $\sim 15 \mathrm{keV}$ net impact energy), with a sample current of $2 \mathrm{nA}$ corresponding to a spatial resolution of $\sim 15 \mu \mathrm{m}$ at the sample surface. The secondary ion accelerating voltage of $4,500 \mathrm{~V}$ was offset by $75 \mathrm{eV}$ (energy window of $40 \mathrm{eV}$ ) to reduce molecular ion transmission. Calibration was performed on glass standards under identical operating conditions. Statistical precision is better than $10 \%$ relative for all isotopes. Accuracy is better than $10 \%$ relative for REE barium, strontium, niobium, zirconium and yttrium. Hafnium, rubidium, thorium and $U$ are accurate to within $30 \%$ relative.

Subsolidus phase relations were determined in the system $\mathrm{CaSiO}_{3}-\mathrm{CaTiO}_{3}$ $\mathrm{MgSiO}_{3}$ at pressures of 20 to $50 \mathrm{GPa}$ and 1,500 to $2,500 \mathrm{~K}$ using laser-heated diamond anvil cell techniques at University of Bristo ${ }^{34}$. Powdered-glass starting mixtures (doubly-fused and triply ground) with 10 wt \% Pt-black as a laser absorber were loaded into $\sim 100 \mu \mathrm{m}$ holes drilled in pre-indented stainless steel gaskets. Samples were compressed in diamond anvil cells using diamonds with 250 or $300 \mu \mathrm{m}$ culets. Pressure was measured by ruby fluorescence. Samples were heated for 30 to $60 \mathrm{~min}$ using a double-sided heating geometry, with temperature measurement using standard radiometric techniques ${ }^{35}$. Phase identification in P-T quenched samples was determined using focused synchrotron $\mathrm{X}$-ray diffraction at station 9.5 HPT of the SRS, Daresbury Laboratory, UK, and station 12.2.2 at the ALS, Lawrence Berkeley Laboratory, USA. At the SRS a final pair of slits with a rectangular geometry of $\sim 20 \times 40 \mu \mathrm{m}$ truncate the focused X-ray beam. At the ALS, Kirkpatrick-Baez mirrors are used to focus the X-ray beam to a $\sim 20 \mu \mathrm{m}$ diameter spot. We routinely interrogate the central part of the $\sim 80 \mu \mathrm{m}$ radius heated region in several acquisitions (300-900s per acquisition). Wavelength dispersive diffraction spectra are acquired with MAR345 imaging plates at both facilities and data are reduced to intensity-20 plots using FIT2D software. $\mathrm{Mg}$-perovskite and $\mathrm{Ca}(\mathrm{Ti}, \mathrm{Si}) \mathrm{O}_{3}$-perovskites are indexed according to $P b n m$ and $P m 3 m$ crystal structures. Full details of all experimental compositions, run products and phase relation are to be presented elsewhere.

A melting experiment in the system $\mathrm{CaO}-\mathrm{MgO}-\mathrm{Al}_{2} \mathrm{O}_{3}-\mathrm{SiO}_{2}-\mathrm{TiO}_{2}-\mathrm{CO}_{2}$ in which Ca-rich carbonate melt coexists with majorite, Ca-perovskite and magnesite was made at $20 \mathrm{GPa}$ and $1,475^{\circ} \mathrm{C}$ using multi-anvil techniques at Bayerisches Geoinstitut (BGI), Germany. A model eclogite starting mixture made of powdered glass and magnesite $\left(\mathrm{MgCO}_{3}\right)$ was placed within a platinum capsule and run at high pressure and temperature in a 10/5-type pressure cell using a 1,200 ton press and a 'Kawai'-type anvil geometry. The sample was held at temperature for $30 \mathrm{~min}$ and then quenched. Electron microprobe analyses of the mineral and melt phase in the run product was made at BGI with a JEOL JXA8900 microprobe using silicate and oxide standards, a beam current of $15 \mathrm{nA}$ and a $15 \mathrm{kV}$ voltage with conventional $\mathrm{ZAF}$ data reduction techniques. Full details are to be presented elsewhere.

34. Walter, M. J. et al. Subsolidus phase relations and perovskite compressibility in the system $\mathrm{MgO}-\mathrm{AlO}_{1.5}-\mathrm{SiO}_{2}$ with implications for Earth's lower mantle. Earth Planet. Sci. Lett. 248, 77-89 (2006).

35. Walter, M. J. \& Koga, K. T. The effects of chromatic dispersion on temperature measurement in the laser-heated diamond anvil cell. Phys. Earth Planet. Inter. $143-144,541-558$ (2004). 


\section{DISCLAIMER}

This document was prepared as an account of work sponsored by the United States Government. While this document is believed to contain correct information, neither the United States Government nor any agency thereof, nor the Regents of the University of California, nor any of their employees, makes any warranty, express or implied, or assumes any legal responsibility for the accuracy, completeness, or usefulness of any information, apparatus, product, or process disclosed, or represents that its use would not infringe privately owned rights. Reference herein to any specific commercial product, process, or service by its trade name, trademark, manufacturer, or otherwise, does not necessarily constitute or imply its endorsement, recommendation, or favoring by the United States Government or any agency thereof, or the Regents of the University of California. The views and opinions of authors expressed herein do not necessarily state or reflect those of the United States Government or any agency thereof or the Regents of the University of California. 